\title{
Valuations and Decisions of Investing in Corporate Social Responsibility: A Real Options Viewpoint
}

\author{
Kuo-Jung Lee ${ }^{\circledR}$ \\ Department of Commerce Automation and Management, National Pingtung University, 51, Minsheng E. Rd., \\ Pingtung City 90004, Taiwan; kjlee@mail.nptu.edu.tw; Tel.: +886-8-766-3800 (ext. 31667); Fax: +886-8-721-0801
}

Received: 21 August 2018; Accepted: 27 September 2018; Published: 1 October 2018

check for updates

\begin{abstract}
Corporate social responsibility (CSR) implementation could raise corporate reputations and benefit long-term development. Studying the effects of CRS on corporate valuation is essential. However, studies on the valuation of CSR are limited, particularly studies involving a dynamic model for valuing CSR. This study applies a real options approach to derive the company valuation of CSR investments, CSR options value, and the optimal timing for implementing CSR. This study elucidates the value of CSR and the decision to invest in CSR. Specifically, the value of CSR options facilitates determining whether to invest in CSR, and the optimal threshold for implementing CSR indicates explicitly when to invest in CSR. In addition, numerical analyses and results are demonstrated to verify the established model. This is the first and novel attempt to consider the valuation model and optimal strategies of CSR investments using the methods of real options.
\end{abstract}

Keywords: corporate social responsibility; real options; company valuation; investment timing; optimal decisions

\section{Introduction}

Corporate social responsibility (CSR) has not only garnered academic discussion but also attracted the attention of enterprises and society. The World Business Council for Sustainability and Development defines CSR as the continuing commitment by a business to contribute to economic development while improving the quality of life of the workforce and their families as well as of the community and society at large. Accordingly, the goal of an enterprise during operation is to not only maximize its shareholders' interests but also to show concern for stakeholders, socially disadvantaged groups, and environmental protection. Moreover, CSR has become a goal pursued by enterprises, because its implementation can improve corporate images and benefit long-term corporate development. To survive global competition, enterprises should promote their image and develop relationships with local communities through CSR.

Generally, CSR is regarded as a public service (e.g., philanthropy and charitable activities) undertaken by enterprises; however, this perspective is exceedingly narrow. In addition to charitable activities, enterprises bear not only economic and legal obligations but also other responsibilities to the society, according to the concept of CSR. Aupperle et al. [1] argue that CSR refers to a society's expectations in terms of the economy, law, ethics, and initiative of an organization during a specific timeframe. Wood [2] defines CSR as the configuration of related principles or any CSR-related strategies and plans adopted during social responsiveness. According to Dell et al. [3], CSR denotes obligations that a firm must fulfill to protect and enhance the society it is in. In terms of CSR, firms should account not only for their shareholders but also all levels of stakeholders including employees, customers, upstream and downstream firms, communities, and the environment.

In the past two decades, CSR has been increasingly emphasized by government agencies, businesses, and the public. The rise of environmental awareness has also prompted investors 
to approve of environment-related CSR activities taken by businesses. Previous studies on the correlation between CSR and corporations' financial performance have mainly investigated whether corporate investment on CSR can enhance or create corporate value and effectively improve corporate performance. CSR implementation could increase brand awareness and corporate reputation, thus benefiting long-term corporate development. Nevertheless, CSR expenditures cannot be ignored. The relationship between CSR and corporate performance has been widely investigated. Studies including those of McWilliams and Siegel [4] and Krüger [5] consider that the results of CSR investments are inconsistent. This inconsistency shows that the performance of CSR investments is complicated and uncertain. Although implementing CSR has a positive impact and is a current trend, CSR investors could suffer a great loss. A real options approach is suitable to value the uncertainty of CSR investments. Especially, the optimal timing to invest in CSR can be derived from the real options approach, and that can help the firms to make the best decisions relating to CSR. A real options approach is therefore a great method when facing the problem of uncertainty.

Scholars have widely adopted real options theory to evaluate investment projects in recent years because flexibility in investment decision-making is valuable under market uncertainties [6]. However, only a few studies use the real options viewpoint to analyze CSR investments [7-10]. These researchers use the real options framework to study CSR investments, but they do not construct a pricing model for investigating CSR investments. According to a review of the literature, this study is the first to derive the closed-form solution of optimal threshold of CSR investments.

The main purpose of this study is to construct a dynamic CSR valuation model. This study elucidates the value of CSR and the decision to invest in CSR. Specifically, the value of CSR options facilitates determining whether to invest in CSR, and the optimal threshold for implementing CSR indicates when to invest in CSR. This study assumes that sales profits follow a stochastic process and that company value varies with sales profits. Moreover, the real options approach is applied to derive the company valuation of the CSR investments and determine the threshold for implementing CSR. In addition, numerical analyses and results are presented to verify the established model. Compared to the related literature, this paper contributes to the literature in several ways. First, this paper constructs a dynamic model in an uncertain environment to explain companies' behavior regarding CSR investments. This model, being different from the standard Black-Scholes formula, offers more flexibility to verify a company's strategy. In this paper, a real options approach is applied to derive the closed-form solution of CSR investments, CSR options value, and the threshold for implementing CSR. The optimal timing to invest CSR can be an answer to the inconsistent problem regarding CSR performance. In addition, the findings of the numerical analysis verify that an industry boom with rising product prices is conducive to companies' investments in CSR. When the investment threshold is higher, the options value approximates 0 regardless of CSR costs.

The rest of this paper is organized as follows: Section 2 presents a literature review that summarizes relevant research on CSR and real options and provides a base for the subject of the current study. In Section 3, this paper applies a real options approach to construct a CSR valuation model. Section 4.1 focuses on the timing to invest in CSR. Section 4.2 provides numerical analyses and their results, verifying the established model. Finally, Section 5 presents the conclusions.

\section{Literature Review}

\subsection{CSR and Its Performance}

With the increasing importance of CSR in businesses, the literature on CSR is also growing. Numerous studies have examined the motives for and determinants of CSR, as well as the economic consequences of CSR [11]. An increasing number of studies investigate beyond the link between CSR and financial performance [12-14] and examine the effect of CSR on other dimensions of firm actions and outcomes such as firm risk [15], cost of capital [16,17], and financial reporting [18-21]. 
Existing models of CSR behavior primarily belong to two categories [22]. The first involves models in which CSR expenditures improve operating income, and the second category comprises CSR models that assume that CSR expenditures are made because the corporate decision-makers or other nonshareholders or stakeholders feel positive at having supported their community with CSR spending, even when this has no benefit for operating income. Barnea et al. [22] determine that some investors gain utility from owning companies that are active in CSR. They demonstrate that the investors' portfolio choices affect stock prices such that value-maximizing managers make CSR expenditures.

More recent research has investigated how CSR benefits firms to explain CSR within the benchmark model of the firm as a profit-maximizing entity. In this regard, resources allocated by firms to environmentally benign conduct, enlightened employment policies, charitable giving, and other socially worthy activities constitute investments in relationships with key stakeholders [23]. Warm attitudes on the part of customers, suppliers, employees, and regulators result in enhanced brand value [4,24], lower employee turnover [25], reduced risks of adverse government or activist action [26], and, ultimately, greater returns on investors' capital [27-30].

Navarro [31] and Webb [32] assume that corporate donations are part of a firm's advertising strategy. Navarro [31] assumes that CSR spending improves the quantity of sales of the firm's product at any price, whereas Webb [32] considers that CSR spending improves price, at any given output level. Barnea and Rubin [33] test a model in which management makes CSR expenditures to maximize its self-interest at the expense of shareholders. They reveal some evidence consistent with this agency theory.

Related studies examining the relationship between CSR and profitability represent relatively mixed results. Some studies identify a positive relationship, whereas others represent a negative or no relationship [5]. In particular, the question as to why firms must invest in CSR has been a subject of debate over the past 20 years [4]. From the perspective of value enhancement, CSR can enhance shareholder wealth [34-42]. In these studies, Li et al. [42] reject the over-investment hypothesis that more powerful CEOs tend to invest more in CSR activities for their own reputation building. They confirm that CSR activities are positively related to firm value and value-enhancing. By contrast, Cheng et al. [43] opine that CSR is the manifestation of a firm's agency problems. Krüger [5] also believes that CSR primarily benefits managers who earn a good reputation among key stakeholders. From an alternative perspective of agency problems, positive news about CSR is bad news for shareholders. The relationship between CSR and corporate performance has been widely investigated. The results of recent studies tend to confirm a positive relationship between CSR and corporate performance. Studies reach dissimilar conclusions because of differences in samples, methods, and industrial characteristics. In addition, the public in different societies and countries have different opinions regarding CSR. The effects of CSR benefits for companies in different environments are different. Most important of all, we can realize that CSR investments are complicated and uncertain. The benefits (e.g., good reputation) of implementing CSR are not easy to value. After investing in CSR, some firms obtain a profit, whereas others suffer a great loss. In this uncertain situation, a real options approach is appropriate to value the profits of CSR investments. This paper represents the viewpoints that real options can be used to evaluate CSR in the following.

\subsection{CSR and Real Options}

Addressing questions related to CSR investments is essential. Traditional valuation methods (e.g., the net present value (NPV) method) that are used in investment valuation fail to assess the time and operational flexibility of planning, and they consequently underestimate the value of investment planning [44,45]. Husted [7] believes that firms often abandon CSR investments when they apply traditional valuation techniques to analyze the cost and benefits of CSR. Furthermore, Cassimon et al. [10] emphasize that the NPV or a cost-benefit approach ignores the strategic value of CSR investments. To overcome the drawbacks of traditional valuation methods, a real options 
approach is often applied. Using this approach, investors could defer the decision on investments until a certain environmental characteristic has revealed itself. A real options approach is very popular in the corporate world because of its viability for strategic management and risk analysis [46].

Several scholars in recent years have adopted a real options approach in the context of investment plan valuation. One advantage of a real options approach is that the value of management flexibility in investment strategies is considered under an uncertain market; hence, the real value of investments can be captured more accurately. Another advantage is that optimal strategies in an investment can be derived accordingly [47]. Specifically, the real options approach can not only capture the real value of an investment or a project more accurately but also help illuminate strategies that could be used during investment. McDonald and Siegel [48] and Hsu and Lambrecht [49] emphasize that investing under uncertainty and irreversibility implies renouncing the options to invest in the future; therefore, investment consideration is a trade-off between postponing investment profits and renouncing such options. McDonald and Siegel [50] and Dixit and Pindyck [51] also propose that the execution of an investment plan can be regarded as owning an option under the uncertainties of cost and price. Ziedonis [52] identifies that firms are more likely to purchase option contracts for more uncertain technologies. Other theoretical works include those of Carr [53], Ritchken and Rabinowitz [54], Myers and Majd [55], and Lund [56].

CSR issues and real options approaches have been rapidly developing in the research field. However, studies applying real options theory to study CSR are very limited. Regarding related studies, Husted [7] argues that CSR is a type of real option. He defines CSR investment as exercising a call option on the benefits of CSR by paying a particular investment cost of CSR. Using real options theory, Husted [7] develops the notion of CSR as a real option and its implications for risk management. He suggests that CSR should be negatively related to a firm's ex ante downside business risk. Peters et al. [9] explore the conceptual relationship between CSR orientation and real option reasoning. They argue that the firm's attitude, communication, and behavior toward CSR are major determinants of the firm's sense-making approach to real options. Integrating the previous work of Basu and Palazzo [57] and that of Barnett [58], they propose a new model that extends the influence of CSR orientation to general strategic decision-making while developing the attention-based view to real options. Cassimon et al. [10] also use a real options framework to study CSR investment. They extend the Husted [7] model to explain CSR investment behavior. They present the timing of CSR investment and explain why some companies delay CSR investments.

Although the reviewed studies apply the real options perspective or framework to investigate CSR, they mainly explain the strategic values and decisions of CSR and do not construct a model for pricing the value of CSR. This paper highlights that the approach is distinct from prior CSR literature that uses the standard Black-Scholes formula [7-10]. This study constructs a real-options-based model for evaluating firms and their CSR investment decisions under a dynamic environment. In addition, this study derives a closed-form solution of options and the optimal timing of CSR investment. A corresponding numerical analysis is then conducted for different scenarios with respect to the options value and the threshold of CSR. On the basis of the solutions and numerical analysis, this study reports a number of findings.

\section{Basic Model Based on Real Options Approach}

Even if immediate CSR investments may increase a firm's value, it is possible that deferring CSR investments is the better option. The options value can be used to judge whether investing in CSR is worthy for the firm. The options value is measured by using the real options approach. This study attempts to construct the dynamic model for evaluating firms and their CSR investment decisions. In this model, a real options approach is applied to obtain the firm valuation of CSR investments in this section. The CSR options value and the optimal timing for implementing CSR are then derived in the following section. 
In an uncertain environment, the firm's value is determined by a stochastic variable, and this uncertainty could be linked to shocks in output prices, $p_{t}$. According to the models of Lee [47], Schwartz and Torous [59], and Lambrecht [60], this study constructs the basic model and assumptions. Assume that a firm's output price, $p_{t}$, follows a geometric Brownian motion:

$$
d p_{t}=\alpha p_{t} d t+\sigma p_{t} d z
$$

where $\alpha$ denotes the expected growth rate parameter, $\sigma$ denotes the volatility parameter, and $d z$ denotes the increment of the standard Wiener process. These assumptions and settings above are common and have appeared in many studies. In addition to output prices [47,60], a similar assumption can be applied to the stock price, the present value of cash flows [61], demand shock [59], and so on. Firm $i$ 's cost per unit of input in $L_{i}$ is denoted by $w_{L}$. The firm's instantaneous profit function is given as follows:

$$
\pi_{i}\left(p_{t}\right)=\max _{L_{i}}\left[\left(p_{t}-p_{c}\right) q\left(L_{i}\right)-w_{L_{i}} L_{i}\right]
$$

where $p_{c}$ is a wholesale price or transfer price, which is assumed to be identical for all firms in this study. The output is determined using a Cobb-Douglas production function:

$$
q\left(L_{i}\right)=L_{i}^{a} K_{i}^{b} .
$$

In the preceding equation, $L_{i}$ denotes the variable production input (e.g., labor) of firm $i$, whereas $K_{i}$ is fixed (e.g., capital). Furthermore, the superscripts $a$ and $b$ denote parameters of economies of scale.

The preceding equation suggests that profit maximization requires that $\partial \pi_{i} / \partial q_{i}=0$. Therefore, it is straightforward to demonstrate that, in equilibrium,

$$
L=\left(\frac{a\left(p_{t}-p_{c}\right) K^{b}}{w_{L}}\right)^{\frac{1}{1-a}}
$$

For convenience of calculation, let $p_{t}-p_{c}=c p$ and $0 \leq c \leq 1$. Substituting the equilibrium production into $\pi$ yields the firm's profit, when the variable input is chosen optimally, as follows:

$$
\pi_{i}\left(p_{t}\right)=\left(a^{a \gamma}-a^{\gamma}\right)\left(\frac{c p K^{b}}{w_{L}^{a}}\right)^{\gamma} \equiv \phi\left(a, w_{L}\right)\left(c p K^{b}\right)^{\gamma}
$$

where $\gamma=\frac{1}{1-a}$ and $\phi\left(a, w_{L}\right)=\left(a^{a \gamma}-a^{\gamma}\right) w_{L}^{-a \gamma}$.

Applying Ito's lemma yields a dynamic program of profit function:

$$
\frac{d \pi\left(p_{t}\right)}{\pi\left(p_{t}\right)}=\left[\alpha \gamma+\frac{1}{2} \gamma(\gamma-1) \sigma^{2}\right] d t+\gamma \sigma d z
$$

If one assumes that investors are risk-neutral and that a risk-free asset exists, yielding a constant interest rate, $r$, at which investors may borrow or lend freely [51], the value of the firm without engaging in CSR can be given as follows:

$$
V\left(p_{t}\right)=\frac{\phi\left(c K^{b}\right)^{\gamma} p^{\gamma}}{r-\gamma(r-\delta)-\frac{1}{2} \gamma(\gamma-1) \sigma^{2}} \equiv \psi p^{\gamma}
$$

where $f(\gamma)=\gamma(r-\delta)+\frac{1}{2} \gamma(\gamma-1) \sigma^{2}$ and $\psi=\frac{\phi}{r-f(\gamma)}\left(c K^{b}\right)^{\gamma} \cdot f(\gamma)$ can be considered the growth rate in the Gordon model, and $\psi$ can be considered the quantity index. The value of the firm can be regarded as the discounted value of all future profits. 
CSR implementation could increase brand awareness and improve corporate reputation, thus benefiting corporate development. Compared with a general company, engaging in CSR could help a company to increase its output; this is formulated as follows:

$$
q\left(L_{i}\right)=I_{R} L^{a^{\prime}} K^{b^{\prime}}
$$

where $I_{R}$ represents the CSR index and $I_{R} \geq 1$. The parameters $a^{\prime}$ and $b^{\prime}$ are scale parameters of labor and capital. If the efficiency of CSR can be developed, $a^{\prime}>a$ and $b^{\prime}>b$. When the labor input is chosen optimally and the same aforementioned approach is applied, the value of the firm engaging in CSR, $V_{C S R}$, is given as follows:

$$
V_{R}\left(p_{t}\right)=\psi_{R} p^{\gamma_{R}}
$$

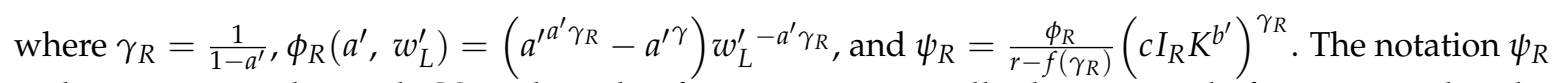
is the quantity index with CSR. The value function is essentially the same as before, except that the CSR index is now considered and that the scale parameters are now presented as $a^{\prime}$ and $b^{\prime}$, rather than $a$ and $b$. The effect of CSR on corporate value can be presented as

$$
\frac{\partial V_{R}\left(p_{t}\right)}{\partial I_{R}}=\gamma_{R} I_{R}^{\gamma_{R}-1} \psi_{R} p^{\gamma_{R}}>0
$$

The result shows a positive relationship between the CSR index and corporate value. Engaging in CSR enhances the corporate value, and this value increasing depends on the CSR index, $I_{R}$. That is, increasing the CSR index $\left(I_{R}\right)$ and scale parameters of labor and capital $\left(a^{\prime}\right.$ and $\left.b^{\prime}\right)$ will be a benefit to the firm's output and value. However, the cost of CSR is not considered yet. This further calculation will be analyzed in the following section.

Regarding the relationship between CSR and corporate value, some studies determine a positive relationship, whereas others identify a negative or no relationship [5]. In addition, many cases of failure are evident, even when firms paying much attention to CSR have invested considerable money. First of all, this paper derives the firm's value when facing the CSR environment of uncertainty and large cost. In addition to the advantage of output, this paper further considers the cost of CSR investment in the following model to ensure that CSR firms make the right decisions. Giroud and Mueller [62] find that weak governance firms have lower labor productivity and higher input costs, and make more value-destroying acquisitions in noncompetitive industries. When the firms are engaged in CSR, they will have higher labor productivity and lower input costs. By Equation (9), this means that $a^{\prime}>a$ and $w_{L}^{\prime}>w_{L}$, and the value of firms to engage in $\operatorname{CSR}\left(V_{R}\right)$ is thus increasing.

\section{Results}

\subsection{Options and Timing of CSR Investments}

In this section, the CSR options and timing of investing in CSR are studied. When considering a CSR investment, firms face a trade-off between the stochastic benefits and the costs of CSR, $C_{R}$. Because investing in CSR is an option and not an obligation for the investors, they invest only when doing so serves their interest. The CSR options are as follows:

$$
O\left(p_{t}\right)=\left[\psi_{R} p^{\gamma_{R}}-\psi p^{\gamma}-C_{R}\right]
$$

The term $\psi_{R} p^{\gamma_{R}}-\psi p^{\gamma}$ represents the benefits of investing in CSR. The benefits will increase by the increasing output price and quantity index with CSR. The options value increases when the benefits increase and costs of CSR decrease. 
According to the assumptions of the model, the demand shock follows a geometric Brownian motion. The ordinary differential equation of a CSR option is as follows (refer to Dixit and Pindyck, [51]):

$$
\frac{1}{2} \sigma^{2} p_{t}^{2} O^{\prime \prime}\left(p_{t}\right)+(r-\delta) p_{t} O^{\prime}\left(p_{t}\right)-r O\left(p_{t}\right)=0
$$

According to Dixit and Pindyck [51], the solution of the preceding equation has the following form:

$$
O\left(p_{t}\right)=B p^{\beta}, \beta>0
$$

where $B$ and $\beta$ are constants to be determined. The expression for $\beta>0$ can be obtained by solving the following fundamental quadratic equation:

$$
\mathrm{Q} \equiv \frac{1}{2} \sigma^{2} \beta(\beta-1)+\beta(r-\delta)-r=0 .
$$

This study must consider the boundary conditions to be satisfied at a threshold value for entry to close the model:

$$
\begin{gathered}
V(\bar{p})+O(\bar{p})=V_{R} \\
V^{\prime}(\bar{p})+O^{\prime}(\bar{p})=V_{R}^{\prime}
\end{gathered}
$$

where $\bar{p}$ is the threshold to implement CSR investments. Equation (14) is referred to as the value-matching condition. The second boundary condition, Equation (15), is called the high-order contact or smooth-pasting condition. Through the use of the aforementioned boundary condition, $B$ can be solved as follows:

$$
B=\left[\psi_{R} p^{\gamma_{R}}-\psi p^{\gamma}-C_{R}\right] \bar{p}^{-\beta} .
$$

The first investment in CSR occurs when the state variable $p_{t}$ reaches the threshold $\bar{p}$ from below. The value of the firm's option to invest in CSR is given as follows:

$$
O\left(p_{t}\right)=\left[\psi_{R} p^{\gamma_{R}}-\psi p^{\gamma}-C_{R}\right]\left(\frac{p_{t}}{\bar{p}}\right)^{\beta}
$$

Interpreting the aforementioned expressions for the value of the CSR options is simple and intuitive. The first factor represents the surplus, $\left[\psi_{R} p^{\gamma_{R}}-\psi p^{\gamma}-C_{R}\right]$, generated at the time of investing in CSR. The factor, $\left(p_{t} / \bar{p}\right)^{\beta}$, can be considered a discount factor that discounts the surplus back to the present. Lambrecht (2004) determines that the discount factor can also be interpreted as the probability of the state variable ever reaching the CSR threshold, $\bar{p}$, given the current level, $p_{t}$, of the state variable. When the condition of $\partial O(\bar{p}) / \partial \bar{p}=0$ is used, the ordinary differential equations (ODE) of CSR can be derived:

$$
\left(\beta-\gamma_{R}\right) \psi_{R} p^{\gamma_{R}}-(\beta-\gamma) \psi p^{\gamma}-\beta C_{R}=0 .
$$

The threshold $\bar{p}$ can be used as the standard for addressing the problem of when to invest in CSR. The optimal threshold for investing in CSR can be derived as follows:

$$
\bar{p}=\left[\frac{\beta C_{R}}{(\beta-\gamma)\left(\psi_{R} p^{\gamma_{R}}-\psi p^{\gamma}\right)}\right]^{\frac{1}{\gamma}} .
$$

The optimal timing, $T$, to invest in CSR can be denoted as follows: $T=\inf [t \geq 0: p(t) \geq \bar{p}]$. According to the preceding solution of the optimal threshold, this study determines that the optimal threshold comprises three terms: the first term, $C_{R}$, represents the CSR cost effect. Increasing the costs of CSR increases the threshold to invest in CSR. The second term, $\beta /(\beta-\gamma)$, represents the hysteresis factor, and $\beta>\gamma$. When the value of a hysteresis factor increases, the threshold to invest in CSR is increased and the CSR investment is delayed. In addition, increasing uncertainty $(\sigma)$ lowers $\beta$, thereby 
increasing the hysteresis factor and subsequently the CSR threshold. A standard result from real options theory is that a higher level of uncertainty delays investments [51]. The third term represents the synergy factor, $\psi_{R} p^{\gamma_{R}}-\psi p^{\gamma}$. This synergy factor $\left(V_{R}-V\right)$ can be viewed as a result of engaging in CSR, and the result will be affected by the CSR index $\left(I_{R}\right)$ and scale parameters of labor and capital $\left(a^{\prime}\right.$ and $\left.b^{\prime}\right)$. When the quantity index with CSR, $\psi_{R}$, and output price with CSR increase, the CSR synergy increases. The CSR benefit hence increases and CSR investment is expedited. For example, Giroud and Mueller [62] find that firms in noncompetitive industries should benefit relatively more from good governance. In this case, investing in CSR will increase CSR synergy and then decrease the optimal threshold $(\bar{p})$ for investing in CSR. That is, the firms will advance the optimal timing of CSR investments in noncompetitive environments.

This paper builds the theoretical model to derive the optimal timing of CSR investments. When the revenue of investing in CSR is larger than the CSR cost, CSR investment obtains a positive profit and is a good investment decision. However, when the CSR environment is unfavorable to companies (i.e., CSR cost and hysteresis factor are higher and synergy factor decreases), they should defer the investment decisions until the investment conditions of CSR have changed.

\subsection{Numerical Results and Discussions}

This study derives firm values, options values, and the optimal timing of investing in CSR; therefore, a numerical analysis of the results is necessary.

\subsubsection{The Parameter Settings}

In this section, the numerical analysis is used to study the optimal valuations and decisions of CSR investments. From the previous section, the closed-form solutions for options and the optimal threshold of CSR investment are derived. This paper uses numerical analysis to explore further the effects of investment conditions on options value and the optimal threshold. We have to set parameters to conduct a numerical analysis. The parameter values in this study are outlined as follows: the risk-free interest rate is $2 \%$, the convenience yield $\delta$ is $1 \%$, the output price is $1.2, \beta$ is 1.4, $C_{R}$ is 0.6., $\gamma$ and $\gamma_{R}$ are 1.2 and 1.5, respectively, and $\psi$ and $\psi_{R}$ are 1.5 and 2, respectively. On the basis of the preceding information and assumptions, this study first conducts a sensitivity analysis among the options value, investment threshold, and CSR costs; the result is presented in Figure 1. The following analysis and discussion are the options value with different CSR costs and investment efficiencies in Figure 2. The impacts of changes in CSR costs and investment efficiencies on the optimal thresholds are analyzed in Figure 3. The thresholds with different output prices and CSR investment efficiencies are represented in Figure 4.

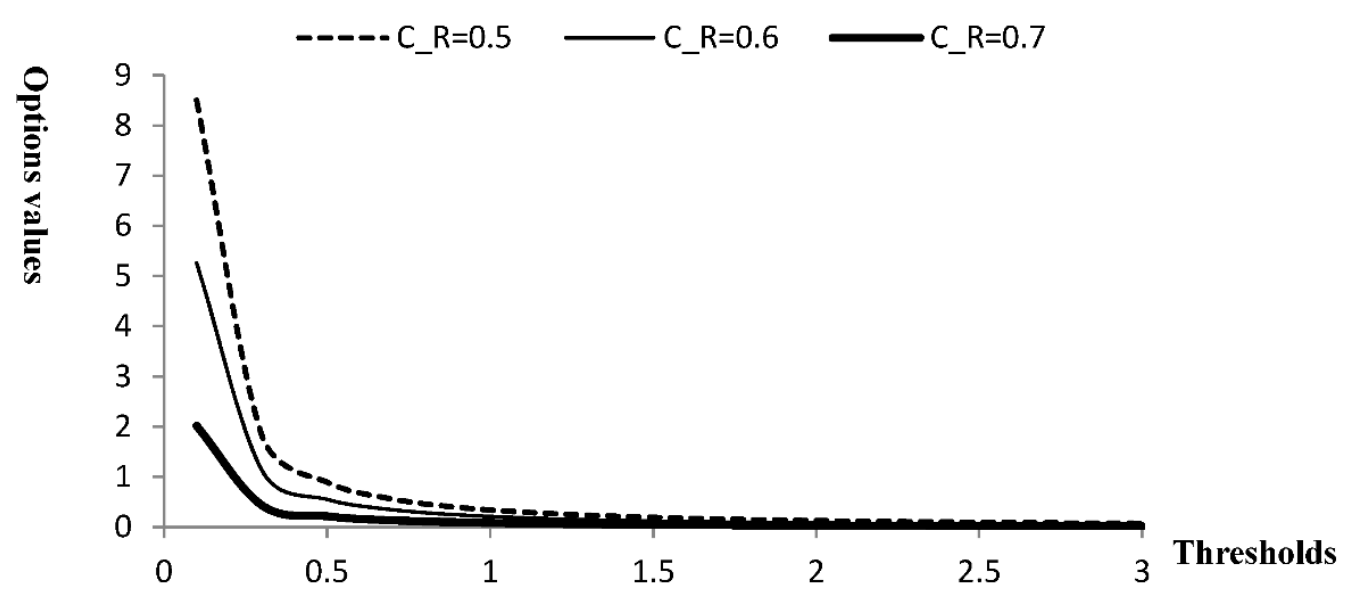

Figure 1. The options value with different price threshold and corporate social responsibility (CSR) costs. 


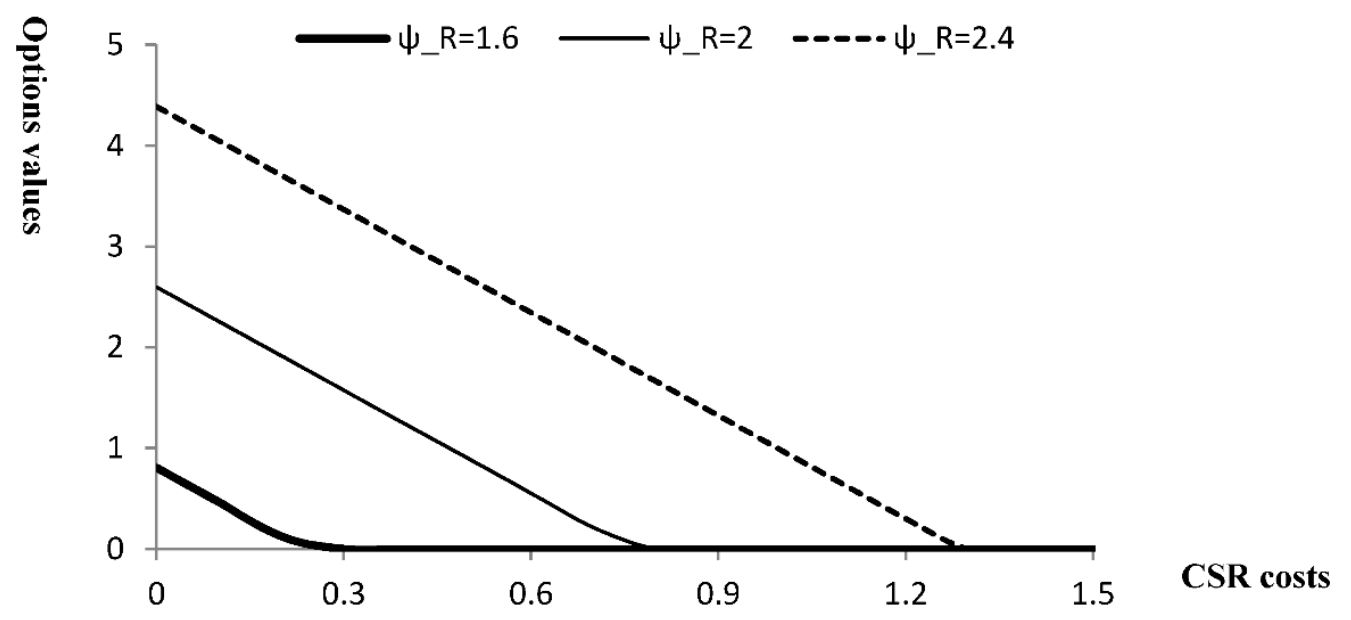

Figure 2. The options value with different CSR costs and investment efficiencies.

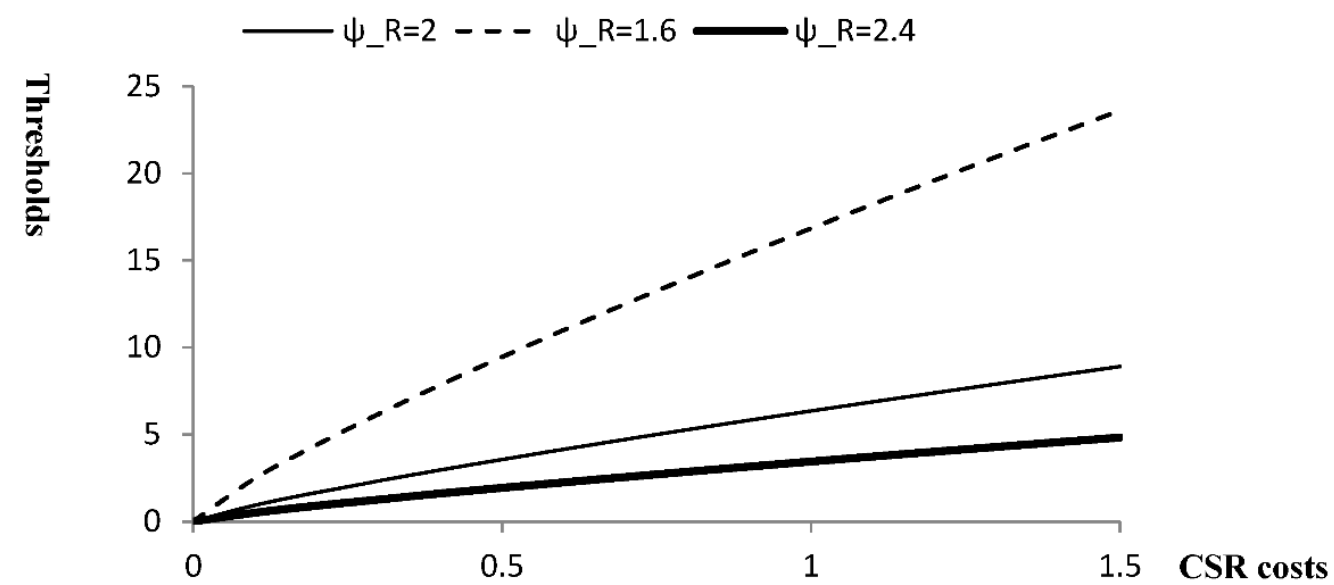

Figure 3. The thresholds with different CSR costs and investment efficiencies.

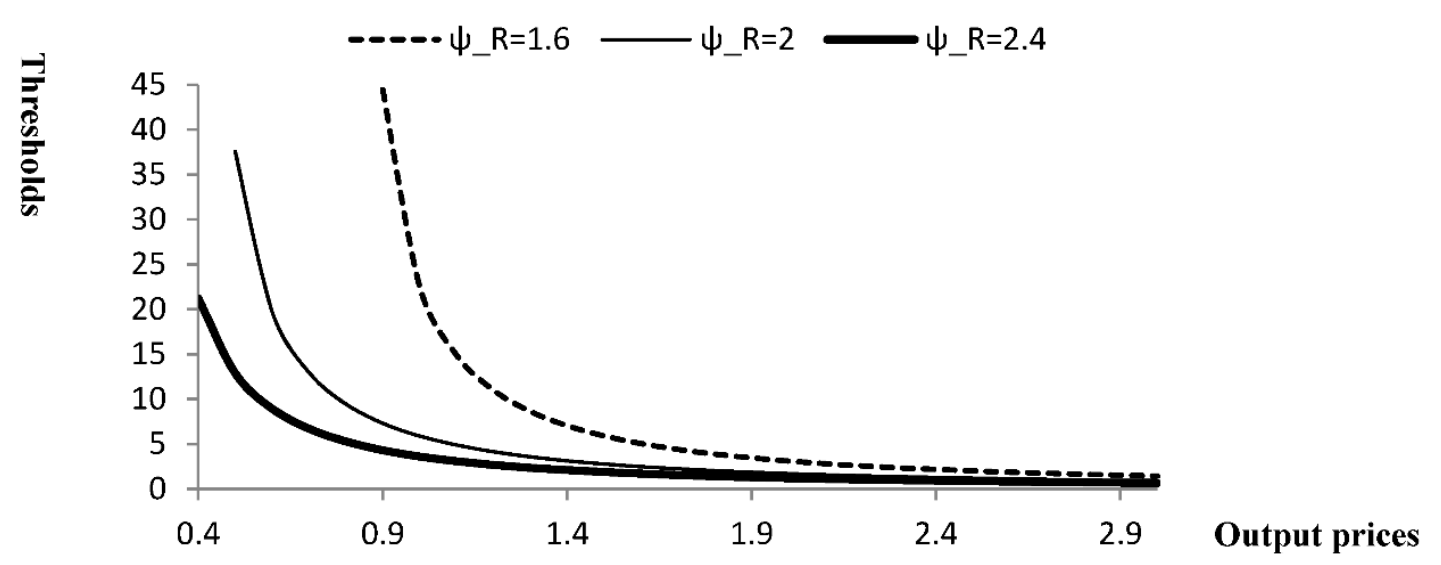

Figure 4. The thresholds with different output prices and CSR investment efficiencies.

\subsubsection{The Effects of CSR on Investment Decisions}

In Figure 1, the vertical axis represents the options value, and the horizontal axis represents the CSR investment threshold, $\bar{p}$. The relationship between $\bar{p}$ and the options value is presented separately according to CSR investment cost $\left(C_{R}\right)$ settings of $0.5,0.6$, and 0.7. In Figure 1 , they are displayed as a dotted line, thin solid line, and thick solid line, respectively. The results show that a high $\bar{p}$ value leads to a low options value, indicating a nonlinear relationship between them. When $C_{R}=0.5$, the options 
value is higher than that when $C_{R}$ is 0.6 or 0.7 , revealing that a low CSR investment cost leads to high CSR benefits and a high options value; this finding is consistent with the general intuition. Regardless of whether $C_{R}$ is 0.5 or 0.7 , the options value approximates 0 when $\bar{p}$ is greater than 1.2 , which indicates a decrease in the likelihood of companies investing in CSR when $\bar{p}$ increases. Under this condition, the impact of $C_{R}$ on the options value is slight.

The vertical axis in Figure 2 represents the options value, and the horizontal axis represents $C_{R}$. The relationship between $C_{R}$ and the options value in this study is presented separately according to the quantity index $\left(\psi_{R}\right)$ settings of $1.6,2$, and 2.4 , which are displayed as a dotted line, thin solid line, and thick solid line, respectively. Because the options value is larger than 0 , it does not exhibit a negative value in the figure. The greater the options value, the more likely and sooner the companies would be to invest in CSR. According to the results, the higher the $C_{R}$ is, the lower the options value is, indicating a negative linear relationship. When $\psi_{R}=2.4$, the options value is greater than that of a $\psi_{R}$ value of 2 and 1.6, showing that high CSR benefits lead to a higher $\psi_{R}$ and thus a high options value. When $\psi_{R}=1.6$, the CSR benefits are low; hence, the options value equals 0 despite the lower $C_{R}$ (e.g., when $\left.C_{R}=0.3\right)$, and the willingness of companies to invest in CSR would be very low. By contrast, when $\psi_{R}=2.4$, the CSR benefits are high; hence, the options value remains positive despite the high $C_{R}$ (e.g., $C_{R}=1.2$ ), reflecting active CSR investment among companies.

The vertical axis in Figure 3 denotes $\bar{p}$, and the horizontal axis denotes $C_{R}$. The relationship between $C_{R}$ and $\bar{p}$ is represented separately according to the quantity index $\left(\psi_{R}\right)$ settings of 1.6, 2, and 2.4. The results show that the higher the $C_{R}$ is, the higher the $\bar{p}$ is, indicating a nonlinear relationship. The relationship under the $\psi_{R}$ value of 1.6 is represented by a dotted line in the figure. Because of the smaller CSR benefits, $\bar{p}$ increases substantially from 0 to 25 as $C_{R}$ increases from 0 to 1.5. The relationship derived from the $\psi_{R}$ value of 2.4 is depicted by a thick solid line. Because of the higher CSR benefits, the increase in $C_{R}$ merely facilitates a slight increase in $\bar{p}$ from 0 to close to 5 . The results indicate that an increase in CSR cost would delay investment timing, whereas an increase in CSR benefits would accelerate investment timing.

The study then discusses the impacts of CSR benefits on $\bar{p}$ (Figure 4). The vertical axis in the figure represents $\bar{p}$, whereas the horizontal axis represents the $p$. The relationship between $p$ and $\bar{p}$ is explored according to the CSR benefits, with $\psi_{R}$ values of $1.6,2$, and 2.4 represented by a dotted line, thin solid line, and thick solid line, respectively. The results indicate that output prices and $\psi_{R}$ are negatively correlated with $\bar{p}$, meaning that an increase in output prices or $\psi_{R}$ leads to earlier investments in CSR by companies. This finding verifies that an industry boom with rising product prices is conducive to companies' investments in CSR. In addition, when the output price is low (i.e., $p<1.2$ ), the investment threshold is high but decreases rapidly with increasing price. When the output price is high (i.e., $p>2$ ), the effects of increasing output price on CSR investments are not significant.

Previous literatures examined the relationship between CSR and profitability and found relatively mixed results. The effects of CSR benefits on companies in different environments are different. These results reflect that the situation of CSR investments is dynamic and complicated. Cassimon et al. [10] indicate that the question as to when a company should invest in CSR is largely underdeveloped. This is an important solution in explaining companies' investment decision. This paper constructs a real options model of CSR investments with fluctuating gross profits and obtains closed-form solutions of firm's value, options, and the optimal timing of CSR investments. Numerical analysis is applied to inspect and study the results of closed-form solutions. Based on those solutions and numerical analysis, this study has a few findings. The results show that an increase in CSR benefits (i.e., increasing output price and quantity index) will accelerate investment timing, whereas an increase in CSR cost will delay it. This finding verifies that an industry boom with rising product prices is conducive to firms' investments in CSR. In this situation, the CSR benefits are high, CSR investments are active, and the options value hence remains positive and large despite the high CSR cost. 


\section{Conclusions}

A few studies including Husted [7], Hitch et al. [8], Peters et al. [9], and Cassimon et al. [10] have used the real options framework to study CSR investments. However, they focus on the conceptual explanation or apply the standard Black-Scholes model to analyze CSR investments. In contrast to the previous studies, this study applies a real options approach to construct a dynamic model for evaluating CSR, in which CSR options are evaluated to determine whether investing in CSR is worthwhile for investors or firms. This study assumes that sales profits follow a stochastic process and that company value varies with sales profits. Accordingly, the real options approach is applied to derive the company and options valuation of CSR investments and the optimal threshold to engage in CSR. In addition, this paper further explores these values based on numerical analysis and firms' corresponding investment decisions. This study sheds some light on the values of CSR investments in a dynamic environment and hence the decisions of investors.

The relationship between CSR and corporate performance has been widely investigated. Implementing CSR has a positive impact and revenue but CSR investors could suffer a great cost. Some studies identify a positive relationship between CSR and profitability, whereas others find a negative relationship [5]. Cheng et al. [43] opine that CSR is the manifestation of a firm's agency problems. By contrast, Li et al. [42] provide strong evidence against the over-investment hypothesis based on the agency theory, confirming that CSR activities are positively related to firm value. Many studies identify that CSR can enhance shareholder wealth. However, the negative relationship may present large cost, low profit, or over-investment of CSR. These dissimilar conclusions in the literature probably result from the differences in samples, methods, and industrial characteristics. The effects of CSR benefits on companies in different environments are different. In addition, these results also reflect that the performances of CSR investments are complicated and uncertain. Kytle and Ruggie [63] think that CSR is considered to be risky because of no definite valuation for the CSR option. Therefore, this study applies a real options approach to construct the dynamic model to derive the firms' valuation and the optimal timing for implementing CSR.

Cassimon et al. [10] indicate that the question is when a company should invest in CSR. A real options approach is suitable to evaluate the uncertainty of CSR investments. With real options, firms can decide whether and further when to invest in CSR. However, related studies cannot exactly determine the optimal timing to invest in CSR. This paper builds the model when firms face a trade-off between the stochastic benefits and the costs of CSR. Firms invest in CSR only when doing so serves their interest. This paper derives the optimal timing to invest in CSR and that can help investors to make the best decisions. When the revenue of investing in CSR is larger than the CSR cost, CSR investment yields a positive profit and is a good investment decision. The investment threshold of CSR is thus low and CSR investment is expedited. However, companies should defer the investment decisions until the investment conditions of CSR have changed if the CSR environment is unfavorable to companies (e.g., the CSR cost and hysteresis factor are higher and synergy factor decreases).

Finally, this study provides numerical analyses and results to verify the established model. This paper shows that the relationship between CSR options and the investment threshold is nonlinear and negative. The numerical results indicate that an increase in CSR cost will delay investment timing, whereas an increase in CSR benefits and output prices will lead to earlier investments in CSR. This study is the first to use a real-options-based valuation model to derive closed-form solutions for options and the optimal timing of CSR investment, and thus contributes substantially to the evaluation of CSR investments. Moreover, this paper elucidates not only the value of CSR but also the decision to invest in CSR.

Funding: This research received no external funding.

Conflicts of Interest: The author declares no conflict of interest. 


\section{References}

1. Aupperle, K.E.; Carroll, A.B.; Hatfield, J.D. An empirical examination of the relationship between corporate social responsibility and profitability. Acad. Manag. J. 1985, 28, 446-463.

2. Wood, D.J. Corporate social performance revisited. Acad. Manag. Rev. 1991, 16, 691-718. [CrossRef]

3. Dell, G.S.; Chang, F.; Griffin, Z.M. Connectionist Models of Language Production: Lexical Access and Grammatical Encoding. Cognit. Sci. 1999, 23, 517-542. [CrossRef]

4. McWilliams, A.; Siegel, D. Corporate social responsibility: A theory of the firm perspective. Acad. Manag. Rev. 2001, 26, 117-127. [CrossRef]

5. Krüger, P. Corporate goodness and shareholder wealth. J. Financ. Econ. 2015, 115, 304-329. [CrossRef]

6. Trigeorgis, L.; Reuer, J.J. Real options theory in strategic management. Strat. Manag. J. 2017, 38, 42-63. [CrossRef]

7. Husted, B. Risk management, real options, and corporate social responsibility. J. Bus. Ethics 2005, 60, $175-183$. [CrossRef]

8. Hitch, M.; Ravichandran, A.K.; Mishra, V. A real options approach to implementing corporate social responsibility policies at different stages of the mining process. Corp. Gov. Int. J. Bus. Soc. 2014, 14, 45-57. [CrossRef]

9. Peters, R.; Waples, E.; Golden, P. A Real Options Reasoning Approach to Corporate Social Responsibility (CSR): Integrating Real Option Sensemaking and CSR Orientation. Bus. Soc. Rev. 2014, 119, 61-93. [CrossRef]

10. Cassimon, D.; Engelen, P.J.; Liedekerke, L.V. When do Firms Invest in Corporate Social Responsibility? A Real Option Framework. J. Bus. Ethics 2016, 137, 15-29. [CrossRef]

11. Kim, Y.; Li, H.; Li, S. Corporate social responsibility and stock price crash risk. J. Bank. Financ. 2014, 43, 1-13. [CrossRef]

12. Roman, R.; Hayibor, S.; Agle, B. The relationship between social performance and financial performance. Bus. Soc. 1999, 38, 109-125. [CrossRef]

13. Jiao, Y. Stakeholder welfare and firm value. J. Bank. Financ. 2010, 34, 2549-2561. [CrossRef]

14. Kim, Y.; Statman, M. Do corporations invest enough in environmental responsibility? J. Bus. Ethics 2012, 105, 115-129. [CrossRef]

15. Lee, D.D.; Faff, RW. Corporate sustainability performance and idiosyncratic risk: A global perspective. Financ. Rev. 2009, 44, 213-237. [CrossRef]

16. Ghoul, S.E.; Guedhami, O.; Kwok, C.C.Y.; Mishra, D.R. Does corporate social responsibility affect the cost of capital? J. Bank. Financ. 2011, 35, 2388-2406. [CrossRef]

17. Goss, A.; Roberts, G.R. The impact of corporate social responsibility on the cost of bank loans. J. Bank. Financ. 2011, 35, 1794-1810. [CrossRef]

18. Gelb, D.; Strawser, J.A. Corporate social responsibility and financial disclosures: An alternative explanation for increased disclosure. J. Bus. Ethics 2001, 33, 1-13. [CrossRef]

19. Petrovits, C. Corporate-sponsored foundations and earnings management. J. Account. Econ. 2006, 41, 335-361. [CrossRef]

20. Prior, D.; Surroca, J.; Tribo, J. Are socially responsible managers really ethical? Exploring the relationship between earnings management and corporate social responsibility. Corp. Gov. Int. Rev. 2008, 16, 160-177. [CrossRef]

21. Kim, Y.; Park, M.S.; Wier, B. Is earnings quality associated with corporate social responsibility? Account. Rev. 2012, 8, 761-796. [CrossRef]

22. Barnea, A.; Heinkel, R.; Kraus, A. Corporate Social Responsibility, Stocks Prices and Tax Policy. Can. J. Econ. 2013, 46, 1066-1084. [CrossRef]

23. Burlingame, D.F. Empirical Research on Corporate Social Responsibility: What Does It Tell Us? Nonprofit Manag. Leadersh. 1994, 4, 473-480. [CrossRef]

24. Atkinson, L.; Galaskiewicz, J. Stock Ownership and Company Contributions to Charity. Adm. Sci. Q. 1988, 33, 82-100. [CrossRef]

25. Greening, D.W.; Turban, D.B. Corporate Social Performance as a Competitive Advantage in Attracting a Quality Workforce. Bus. Soc. 2000, 39, 254-280. [CrossRef]

26. Baron, D.P. Private Politics, Corporate Social Responsibility, and Integrated Strategy. J. Econ. Manag. Strat. 2001, 10, 7-45. [CrossRef] 
27. Segerson, K.; Miceli, T.J. Voluntary Environmental Agreements: Good or Bad News for Environmental Protection? J. Environ. Econ. Manag. 1998, 36, 109-130. [CrossRef]

28. Strahilevitz, M.; Myers, J.G. Donations to Charity as Purchase Incentives: How Well They Work May Depend On What You Are Trying To Sell. J. Consum. Res. 1998, 24, 434-446. [CrossRef]

29. Khanna, M.; Damon, L.A. EPA's Voluntary 33/50 Program: Impact on Toxic Releases and Economic Performance of Firms. J. Environ. Econ. Manag. 1999, 37, 1-25. [CrossRef]

30. Alberini, A.; Segerson, K. Assessing Voluntary Programs to Improve Environmental Quality. Environ. Resour. Econ. 2002, 22, 157-184. [CrossRef]

31. Navarro, P. Why Do Corporations Give to Charity? J. Bus. 1988, 61, 65-93. [CrossRef]

32. Webb, N.J. Corporate Profits and Social Responsibility: "Subsidization" of Corporate Income under Charitable Giving Tax Laws. J. Econ. Bus. 1996, 48, 401-421. [CrossRef]

33. Barnea, A.; Rubin, A. Corporate Social Responsibility as a Conflict between Shareholders. J. Bus. Ethics 2010, 97, 71-86. [CrossRef]

34. Dowell, G.; Hart, S.; Yeung, B. Do corporate global environmental standards create or destroy market value? Manag. Sci. 2000, 46, 1059-1074. [CrossRef]

35. Derwall, J.; Guenster, N.; Bauer, R.; Koedijk, K. The eco-efficiency premium puzzle. Financ. Anal. J. 2005, 61, 51-63. [CrossRef]

36. Sen, S.; Bhattacharya, C.B.; Korschun, D. The role of corporate social responsibility in strengthening multiple stakeholder relationships: A field experiment. J. Acad. Mark. Sci. 2006, 34, 158-166. [CrossRef]

37. Siegel, D.S.; Vitaliano, D.F. An empirical analysis of the strategic use of corporate social responsibility. J. Econ. Manag. Strat. 2007, 16, 773-792. [CrossRef]

38. Edmans, A. Does the stock market fully value intangibles? Employee satisfaction and equity prices. J. Financ. Econ. 2011, 101, 621-640. [CrossRef]

39. Dimson, E.; Karakas, O.; Li, X. Active Ownership. Rev. Financ. Studies 2015, 28, 3225-3268. [CrossRef]

40. Flammer, C. Corporate social responsibility and shareholder reaction: The environmental awareness of investors. Acad. Manag. J. 2013, 56, 758-781. [CrossRef]

41. Servaes, H.; Tamayo, A. The impact of corporate social responsibility on firm value: The role of customer awareness. Manag. Sci. 2013, 59, 1045-1061. [CrossRef]

42. Li, F.; Li, T.; Minor, D.A. Test of Agency Theory: CEO Power, Firm Value, and Corporate Social Responsibility. Int. J. Manag. Financ. 2016, 12, 611-628.

43. Cheng, I.H.; Hong, H.G.; Shue, K. Do Managers do Good with Other People's Money? Unpublished Working Paper; University of Chicago-Booth School of Business: Chicago, IL, USA, 2013.

44. Kulatilaka, N.; Trigeorgis, L. The general flexibility to switch: Real options revisited. Int. J. Financ. 1994, 6, 778-798.

45. Trigeorgis, L. Real Options-Managerial Flexibility and Strategy in Resource Allocation; MIT Press: Cambridge, MA, USA, 1996.

46. Trigeorgis, L. Real options and interactions with financial flexibility. Financ. Manag. 1993, 22, $205-221$. [CrossRef]

47. Lee, K.J. The Real Options Component and Market Value of Taiwan Technological Companies. Emerg. Mark. Financ. Trade 2017, 53, 98-108. [CrossRef]

48. McDonald, R.; Siegel, D. Investment and the valuation of firms when there is an option to shut down. Int. Econ. Rev. 1985, 26, 331-349. [CrossRef]

49. Hsu, Y.; Lambrecht, B.M. Preemptive patenting under uncertainty and asymmetric information. Ann. Oper. Res. 2007, 151, 5-28. [CrossRef]

50. McDonald, R.; Siegel, D. The value of waiting to invest. Q. J. Econ. 1986, 101, 707-727. [CrossRef]

51. Dixit, A.K.; Pindyck, R.S. Investment Under Uncertainty; Princeton University Press: Princeton, NJ, USA, 1994.

52. Ziedonis, A.A. Real options in technology licensing. Manag. Sci. 2007, 53, 1618-1633. [CrossRef]

53. Carr, P. The valuation of sequential exchange opportunities. J. Financ. 1988, 43, 1235-1256. [CrossRef]

54. Ritchken, P.; Rabinowitz, G. Capital budgeting using contingent claims analysis: A tutorial. Adv. Futur. Opt. Res. 1988, 3, 119-143.

55. Myers, S.C.; Majd, S. Abandonment value and project life. Adv. Futur. Opt. Res. 1990, 4, 1-21.

56. Lund, D. Financial and non-financial option valuation. Stochastic Models and Options Values; Lund, D., Øksendal, B., Eds.; North-Holland: New York, NY, USA, 1991; pp. 143-163. 
57. Basu, K.; Palazzo, G. Corporate social responsibility: A process model of sensemaking. Acad. Manag. Revi. 2008, 33, 122-136. [CrossRef]

58. Barnett, M.L. An attention-based view of real options reasoning. Acad. Manag. Rev. 2008, 33, 606-628. [CrossRef]

59. Schwartz, E.S.; Torous, W.N. Commercial Office Space: Testing the Implications of Real Options Models with Competitive Interactions. Real Estate Econ. 2007, 35, 1-20. [CrossRef]

60. Lambrecht, B. The Timing and Terms of Mergers Motivated by Economies of Scale. J. Financ. Econ. 2004, 72, 41-62. [CrossRef]

61. Morellec, E.; Zhdanov, A. The dynamics of mergers and acquisitions. J. Financ. Econ. 2005, 77, 649-672. [CrossRef]

62. Giroud, X.; Mueller, H. Corporate governance, product market competition, and equity prices. J. Financ. 2011, 66, 563-600. [CrossRef]

63. Kytle, B.; Ruggie, J. Corporate Social Responsibility as Risk Management: A Mode for Multinationals; Corporate Social Responsible Initiative Working Paper No. 10; John F. Kennedy School of Government, Harvard University: Cambridge, MA, USA, 2005.

(C) 2018 by the author. Licensee MDPI, Basel, Switzerland. This article is an open access article distributed under the terms and conditions of the Creative Commons Attribution (CC BY) license (http:/ / creativecommons.org/licenses/by/4.0/). 